\title{
Strengthening the Character Education Curriculum: a Study On the Etiquette of Visitation According to the Qur'an Surah Al-Nûr Verses 27-29
}

\author{
Zulheldi ${ }^{1}$, Martin Kustati ${ }^{2}$, Iswantir ${ }^{3}$ \\ \{zulheldizulheldi@gmail.com ${ }^{1}$, martinkustati@uinib.ac.id ${ }^{2}$, iswantir@iainbukittinggi.ac.id ${ }^{3}$ \} \\ Department of Islamic Education, Universitas Islam Negeri Imam Bonjol Padang, Indonesia ${ }^{1,2}$ \\ Faculty of Tarbiyah and Teacher Training, Institut Agama Islam Negeri (IAIN) Bukittinggi, Indonesia ${ }^{3}$
}

\begin{abstract}
Character education has become a necessity in the entire history of mankind. Mankind in all ages strongly demands the presence of educated and civilized people with good character. The good character has become one of the major traits in human life these days. There are three aspects that are strongly emphasized in the holy Qur'an in order to strengthen the character education i.e. faith, knowledge, and habituation. Faith makes a person's character to be really pierced and rooted to the deepest part of him, knowledge makes the character has adequate references to be used as a routine reference, and habituation ensures that the character has become the part of one's identity
\end{abstract}

Keywords. Education, character, faith, knowledge, habituation

\section{Introduction}

The completeness and success of character education is increasingly demanded by its needs in view of various moral and legal issues in people's daily lives. There are still many daily behaviors that indicate and ensure that the perpetrators experience serious character and moral problems [1]-[3]. This problem has become even more complicated considering that the negative character is not only exhibited by the general public, but also by those who should be role models for many people. The success or failure of a character education is of course not only determined by the process or how the character is taught, instilled, and familiarized [4][6]. More substantial than that, whether or not fostering character building is highly connected to how the character education is planned. If the education process is not well designed and planned then of course the chances of its success will be greater. Various theories have been introduced related to how character education should be conducted. If they were examined carefully, the Qur'an also has and has explained the concept of the character education [7][12]. The concept of character education can be seen clearly, for example, the Qur'an teaches about the etiquette of visitation.

Teaching about the etiquette of visitation is certainly not just a transfer of knowledge. Furthermore, teaching here requires every Muslim to be civilized in visiting, unlike the ones in Jahiliyah era. Al-Qur'an mentions that in the process of a visitation, Islam requires the guests to implement the Islamic values attached to every Muslim and they should be realized in every visit to someone's settlement. Here, the concepts of character education can be formulated. 


\section{Literature Riview}

\subsection{Curriculum}

Considering the curriculum is a creation and product of human culture, the curriculum concept curriculum processes to follow the development of educational theory and practice. In addition, curriculum dynamics are also very varied according to the educational concepts or theories adopted.In terms of language, the term curriculum was adopted from Greek, curir, means running, and currere, means the place to race [13]-[16]. Arabic language introduces curriculum as manhaj, which means the bright path that humans travel in life, and this term is then applied in education field [17].

There are various understanding of the curriculum introduced by the experts, ranging from a narrow understanding to a very broad one. Narrowly, for example, the curriculum is interpreted merely to contain a number of subjects given by the teacher or school to students in order to obtain a diploma or certificate. The curriculum is broadly interpreted as all of the activities that are provided for students by the school [18]. According to Law number 20 of 2003 concerning the National Education System, the curriculum is interpreted as a set of plans and arrangements regarding the objectives, content, learning materials, and methods used as guidelines in the preparation of curriculum and syllabus at the education unit level.

There are at least three concepts of the curriculum recognized [19] curriculum as a substance. In this concept the curriculum is interpreted as a plan of learning activities for students or a set of goals to be achieved. In this context it is also said that the curriculum is a document that contains the formulation of objectives, teaching materials, teaching and learning activities, schedules, and evaluations or it is also said to be a written document of mutual agreement of the curriculum makers and educational policy holders with the community; 2) curriculum as a system. In this case the curriculum is said to be part of the school system, the education system, even the community system. The curriculum includes the personnel structure and work procedures on how to structure the curriculum, implement, evaluate and perfect it; and 3) curriculum as a field of study. This is the field of study of curriculum experts. They seek to develop knowledge and curriculum systems. Through literature studies and research, they find various innovations that can enrich and strengthen curriculum studies.

By observing the various definitions above, it can be said that the substance of the curriculum are (1) a set of learning plans, which are usually in the form of written documents, (2) the results of the agreement of all related parties, namely policy holders, curriculum compilers, education providers, and the community, (3) contains objectives, contents, lesson material, activities, methods, evaluations, and other related components, and (4) becomes a reference for achieving the objectives.

\subsection{Character Education}

The term character is transported from Greek, charassein, means to engrave (carve, paint, draw). Forming characters is like carving the gemstones or hard iron. Here the meaning of the term character are interpreted by specific signs or patterns of behavior [20] or, patterns of behavior that are individual, one's moral state. [21]-[25] define characters with psychiatric, moral, or moral qualities that distinguish a person from others. Education, according to [26], means a process conducted by a nation in preparing its young generation to carry out their lives in order to fulfill their life goals effectively and efficiently. According to him education is more than just teaching because education is a process in which a nation fosters and develops 
self-awareness among individuals. Thus, basically education is an effort to improve the ability of human resources to become independent human beings and be able to contribute to society and the nation [27]. The character education or character building is usually interpreted as education that develops character values in a student so that he has values and character as himself, applying these values in his life, both as members of the community and citizens who are religious, nationalist, productive, and creative [28]. In another version, character education is also defined as every effort made to influence or to improve the character of the students. [1] defines character education as a deliberate attempt to help someone understand, pay attention to, and carry out core etiquette values. According to [29], based on the above opinion, when a teacher thinks about the type of character that students want to build, surely when the educator wants their students to be able to understand these values, deeply believe in the truth, and do what he believes, even though he must face challenges, both from within and outside himself. In this case students have the awareness to force themselves to do these values.

According to the Minister of Education and Culture Regulation No. 20 of 2018 concerning Strengthening Character Education in the Formal Education Unit, which is a derivative of Presidential Regulation Number 87 of 2017, there are five main characters that must be prioritized for their development in the education unit. This is the answer to the complaints of some teachers who are hesitant in implementing character education considering there are 18 numbers of characters released by the Ministry of Education and Culture earlier. The five main characteristics of priority are religious (reflecting faith and devotion to God Almighty), integrity (always trying to make himself a person who can be trusted in his words, actions, and work), independent (not dependent on others and use energy, thoughts, and time to realize hopes, dreams, and ideals), nationalists (placing the interests of the nation and state above personal and group interests), and mutual cooperation (reflecting the act of appreciating cooperation and working together to solve joint problems).

\subsection{Al-Qur'an Surah Al-Nûr (24) verses 27-29}

\section{- Theme}

[29] Al-Qur'an surah al-Nûr verses 27-29, which are the object of this study, carry the theme of courtesy visiting or visiting other people's homes. These verses explain in sufficient detail the principle and technical aspects of how a person should visit a house that is owned or occupied by someone else. Field conditions and presuppositions that might occur are described in such detail that they are truly applicable. A person only needs to see or adjust to which conditions he meets in the field and which techniques are suitable for these conditions. In addition, these verses also discuss very deeply related to how a person should visit a house or building that is not intended to be inhabited or used as a residence. When compared to residential areas, even if the house or building together, of course the specifications of this place are different. The place is a public facility or can be used by the public in general, of course for those who are interested and in accordance with the conditions set by the owner or manager.

- The Context of the Verses

Verses 27-29 of surah al-Nur have a historical context which is directly related to the themes they mention. According to [30], verses 27 and 28 were revealed regarding the complaint of an Ansar woman to the Prophet. He said, "O Messenger of Allah, I am at home reluctant to be seen by someone, neither father nor son. But father came to see me. When he was still at home, another person came from my family, while I was still in my original state (not ready to meet someone). So, what should I do. "In order to answer the question or resolve the issue, these two verses come down. The verse 29 is a direct answer to Abu Bakr's question 
to the Prophet. One time he asked about the manners of visiting a shop and lodging found on the way to Sham (al-Wāhid, 1991).Related to the context of the existence of these verses in the Koran, it can be said that the three verses of the surah al-Nûr are in the series of learning or fostering morality of a Muslim. The series begins with verse 21 with the command not to follow the steps of Satan. Next, God forbids bad morals such as being reluctant to help others and accusing good people of adultery. All of these abominations must be avoided because they will all be accounted for in the sight of God based on the testimonies of one's own limbs such as the tongue, hands, and feet. The following verses oblige every believer man and woman to maintain his views and self-respect.

\subsection{Educational Relevance}

The verses above are very relevant and related to education. These verses talk about how character education, that is, civilized characters when visiting or visiting other people's homes, and explaining the teaching material with very clear and detailed. It can be ascertained that through these verses Allah wants Muslims or even humanity to change for the better, that is to be Islamic civilized when they visit and leave improper ways or ignorance. As an educator, Allah teaches us morals e.g. the etiquette of visitation to ones' settlement [31]. He explained in sufficient detail the various arguments and the importance of this topic to be taught and to be implemented, the details of the material that must be mastered to be practiced in daily life, and so forth.

\section{Method}

This research is a qualitative research. Content analysis of al-Qur'an surah al-Nûr verses 27-29 used in this study. The verses that teach about the etiquette of guests are interpreted or explained based on reliable sources, such as other verses from the Qur'an, the Prophet's hadith, and the opinions of the scholars contained in their commentaries [32] [39]. These verses are reviewed and explained in such a way that the education of the Qur'an related to visiting people or visiting other people's homes can be formulated in such a way. The analysis of the research used is the Tarbawi interpretation, which is focusing on analyzing one or several verses of the Qur'an in order to formulate the thought and educational value it contains [39]. In practice, this research method takes seven stages or steps, namely (1) determining the object of research, (2) understanding the general content of the verse, (3) detailing the content of the verse, (4) converting the content of the verse, (5) setting the title and outline, (6) interpret verses, and (7) formulate conclusions.

\section{Result And Discussion}

In character education, especially religious characters and mutual cooperation, through fostering courtesy guests or visiting homes that are not their own, the Qur'an emphasizes three main aspects i.e. faith, knowledge, and habituation. 


\subsection{Aspects of Faith}

The existence of faith is very important in character education, such as courtesy guests. Confidence is a factor that controls a person in doing anything. If someone is convinced that behaving well is a religious obligation, one's belief will always encourage him/her to do so. Conversely, if he is not sure that a crime will be miserable, then he will not try his best to leave the crime. According to the verses, visiting in the right way has a strong connection with the faith. This verse begins with a call to believers. Judging from the pronouns used and the usual application of these pronouns in the Holy Qur'an, there are at least three meanings that can be understood in the relation of faith with the etiquette of visitation, i.e. (1) the verses invite the believers to follow the etiquette of visitation in accordance with Allah's requirements; (2) faith is a prerequisite for the proper implementation of the guest house teaching. If someone does not believe in or one's faith is damaged, one will not be able to implement the message properly; and (3) the implementation of visitation activities is a measure and indicator of faith, or the quality of the visiting activities carried out is a measure of the level of faith it has. The higher or stronger one's faith, the better one conducts the activities.

The visitation is also associated with one of the attributes of Allah, al-îAlim (AllKnowing) of all actions, whether real or hidden. This statement ensures that visiting activities and various surrounding activities are known with certainty by Allah [30]. Through this verse, it is as if Allah wants to state "You must do the visitation according to My conditions. You will definitely get a reply in accordance with what was done because I always supervise and evaluate." From the structure of the sentence used, the message of God related to the etiquette of visitation is similar to the other God's will, which starts with Yâyyuhâ alladzina haman. This can be used as an indicator that the activity of visiting is also a fundamental obligation to have Islam, as with other teachings. When someone visits someone else's house or his own house that is inhabited by someone else, it means that he is carrying out one of the religious obligations. One's interactions with others are not limited to their human relations, but are also related to Allah SWT.

\subsection{Aspects of Knowledge}

The second emphasis on the etiquette of visitation is the aspect of knowledge. The verses emphasize the knowledge of students related to the object of the discussion in complete and detailed manner. A student must know everything that is needed so that he can become a civilized person when visiting or entering a house or building that is not his.

There are some things that students must know so that they can have good manners in visiting one's house or settlement, as follow:

1. The Purposes of the Etiquette of Visitation

One who is taught about the etiquette of visitation must know and understand the purpose of teaching and implementing the teachings. Students need to know what the purpose, usefulness, or wisdom they will get if carrying out the lessons about the etiquette of visiting somebody else's house.

The etiquette of visitation is a path to be a better muslim. Entering someone else's house with permission is a better way and brings glory than if not through the permission of the host (dzâlikum khair lakum). Substantially, no one is willing or willing to other people to freely enter his house. Everyone wants to accept when he is comfortable to do it and perform at his 
best (al-Maragghi, 1946). If a host accepts improperly, both time and attitude, it will cause problems or slander behind the day.

The etiquette in visiting someone else's house will prevent both parties from things that pollute themselves. If someone enters another person's house without permission, resentment from the host or discomfort from guests because they are not served maximally will deliver both of them to the various doors of $\sin$ [33]. These negative feelings will lead to hurt, anger, slander, revenge, arrogance, and so on.

2. The logic in the etiquette of visitation

In order for students to be able to understand, to carry out, and to familiarize the etiquette of visitation, ones must understand the logic of the determination of the visitors. The important questions such as "What exactly is the underlying argument that a person must be civilized in visiting?" and other fundamental questions must be answered and explained thoroughly. Just like any other social activities, the visitation must have the provisions that bring benefits to all parties and eliminate any harm that might result. If someone comes or visits someone else's house without confirmation and gets permission from the host, it is very possible this will cause problems and inconvenience for the host. Not only that, the less conducive atmosphere will drag both parties to prejudice, heartache, and so on which allows the purpose of visiting cannot be completed properly. Even though Islam requires its people to respect guests, the host also respects personal rights that his guests must also highly respect. Prospective guests must provide opportunities for prospective hosts to prepare themselves and their homes rather not cause slander and shame. Prospective guests must also be careful to postpone or cancel his arrival if the host feels it needs to be done [34]. Prospective guests should not force themselves to get the chance to visit as they want because the host also has privacy rights that he must respect.

3. The Rule of Visitation

There are a number of rules for visiting guests that students must know so that they can carry out their activities properly. Some of these conditions are: First, entering with permission, in which someone wants to visit someone else's house, he / she cannot enter the house unless he / she has obtained permission from Ahl al-Bait, ie the person who lives there or the person authorized to give entry permission [35], [36]. Every person who will enter someone else's house, either his own or someone else's house that he has obtained the right to live in, must obtain permission and willingness before entering it. He may not enter as long as he has not obtained the permit, except in emergencies such as disasters, crime, and so on.

The necessity for ahl al-bait permission is highly emphasized by the Qur'an because it is closely related to the personal rights of someone who must be respected by anyone and the readiness of the host in receiving guests [34], [37]. The host should get protection of his privacy rights so that he can have the opportunity to allow or not visit these activities. The host is also very entitled to get the opportunity to prepare well before someone visits him to avoid all slander and things that can lower self-esteem. One must not enter the house of another person at will or force him/herself to visit because of something he considers very important and urgent. Host permission is an absolute requirement in entering someone else's house, whether the host is at home or when they are not at home [38]; al-Zamakhsyari, 2010). Any reason, other than emergencies and the like, cannot be used as an excuse to carry out a visit.

Furthermore, looking at the reasons for verses 27 and 28, the requirement to obtain the permit does not only apply to others, but also to one's own family. This situation was experienced by the Ansar woman who complained and sought a solution to the Prophet. Thus, a member must also ask permission if visiting a good family, both different houses, different rooms, and so on. Islam also stipulates that a person is given the opportunity to ask for 
permission a maximum of 3 times [39]. If three times asking for permission there is no answer or signal that he is allowed, then he must return. When asking permission, guests should also not be in a position that can immediately see inside, but on the side of the door and not leading to the house. also must introduce themselves (MW, 2017; al-Bukhāri, 1981). as follow:

There are several things outlined in these verses related to asking for permission to visit,

- Greetings as the best way to ask permission. There are many ways that someone can do to start asking the ahl al-bait to be allowed to enter his house. This can be done by knocking on doors, ringing bells, or other methods agreed or applicable in certain communities. Of all the ways, the best way is to say hello to ask permission to visit. That is what was explained by Abdullah bin Umar to Zaid bin Thabit (al-Bukhari, 1981) Indeed there are various opinions related to which is better to come first, say hello or ask permission. However, various opinions can be concluded that saying greetings and asking permission must be done and priority is given related to conditions and benefit (Shihab, 2004).

- Ahl al-bait has the right to refuse visitation. If the host is not willing to accept guests with certain reasons, whether objective or subjective, the candidate must not force himself and must return [39]. It is very likely that a guest who will visit does not know the exact circumstances and readiness of the host to visit. For this reason, whether or not a meeting occurs is determined by the decision of the host. If he has activities that must be prioritized, such as having to leave the house, or circumstances that are not possible, such as illness and need a break, then the host has the right to refuse visits. The decision must be accepted and carried out by prospective guests with full willingness. That is the best for him (huwa azkâ lakum).

Second, trespassing. The purpose of this unauthorized entry is that one does not need specific permission from the authorities, as in the first part. Everyone is allowed to enter the house or building because it is intended as a public place such as lodging, shops, restaurants, libraries, houses of worship, and so on [35]. There is no need to enter the building because the place has indeed been provided for everyone who needs it as long as they can comply with all applicable provisions. This is in accordance with the cause of the subsection. According to a history, this verse was related to Abu Bakr who asked the Prophet about the guidance regarding the tavern and lodging found on the way to Sham.

However, there are two things that must be remembered and carried out when visiting these public facilities, as follow:

- In accordance with the designation of the place and needs. If someone is in a public place without relying on the above, one can cause discomfort and problems for others and himself. It cannot be justified if someone uses the place of lodging as area offering merchandise because it will disturb many parties. Also, it is not appropriate if a person or group of people linger in a crowded restaurant or a limited place because it will disturb or hinder other visitors.

- Always protect yourself from deeds that are forbidden by Allah because He is AllKnowing all human actions, both overt and hidden. Why does God give special emphasis in this case, even though this prohibition applies wherever someone is? The reason is because the public place outside the home (usually even far from home) and family or in the midst of strangers. The two conditions will provide more opportunities for someone to do as they pleased than when home or in the midst of someone who is known. 


\subsection{Aspects of Habituation}

The final emphasis given by these verses in character education, especially in the etiquette of visitation, is the aspects of habituation. After someone believes in a teaching, knows all the problems and details, then the teaching content must be practiced continuously in one's life. This is what makes one's character because someone is accustomed to do and crystallize them. There are a number of signs that can be interpreted as a customary command for visiting guests that can be found in the verses:

First, it prohibits all forms of visitation (lâ tadkhlû buyûtan ghaira buyûtikum) unless according to the procedure taught. Prohibiting or prohibiting the process of visiting outside the procedures taught by Allah means that this teaching must be carried out by every Muslim every time they visit (al-Qurthubi, 2010). It is this ongoing implementation that makes it an inseparable part of a Muslim's social habits or routines. These verses do not give anyone the choice or exclusion to apply them, but must be carried out continuously. Second, at the end of verse 27 it is stated to always be remembered the messeage of the verses (la'allakum tadzakkarûn) (al-Zamakhsyari, 2010). The expression clearly indicates that the message about the etiquette of visitation is to always be remembered or carried out every time they visit.

\section{Conclusion}

Character education is education that involves many human dimensions, not only knowledge and skills, but also beliefs and habituation. This is what makes a character that is taught truly become part of the students and will not be separated from it. The character taught is really seen in one's attitude, beliefs, thoughts, words, and daily behavior.According to the Qur'an, character education, as reviewed here in the context of visiting education, is very important to be strengthened or emphasized in three aspects, namely faith, knowledge and habituation. Something that makes al-Qur'an's character education different from other character education concepts is its emphasis and reinforcement on aspects of faith or belief. The Qur'an emphasizes that the question of character (which is part of morality) is not only about human affairs with others or human beings with themselves. Moreover, character is substantially engraved in human interactions and relations with God. According to him, morals are manifestations or real indicators of faith.

\section{References}

[1] T. Lickona, Educating for character: How our schools can teach respect and responsibility. Bantam, 2009.

[2] A. A. Raney, "Expanding disposition theory: Reconsidering character liking, moral evaluations, and enjoyment," Commun. Theory, vol. 14, no. 4, pp. 348-369, 2004.

[3] L. Steinberg and E. S. Scott, "Less guilty by reason of adolescence: developmental immaturity, diminished responsibility, and the juvenile death penalty.," Am. Psychol., vol. 58, no. 12, p. 1009, 2003.

[4] L. Abu, M. Mockhtar, Z. Hassan, and S. Z. D. Suhan, How to develop character education of madrassa students in Indonesia. Universitas Ahmad Dahlan, 2015.

[5] M. W. Berkowitz and M. C. Bier, "What works in character education: A research-driven guide for educators," Wash. DC Character Educ. Partnersh., 2005.

[6] D. K. Lapsley and D. Narvaez, "Character education,” Handb. Child Psychol., vol. 4, 2007.

[7] K. Harto, "Developing character internalization model in Islamic education through value clarification technique," Madania J. Kaji. Keislam., vol. 19, no. 2, 2015.

[8] M. Huda, K. A. Jasmi, M. I. B. Mustari, and A. B. Basiron, "Understanding of Wara'(Godliness) as a Feature 
of Character and Religious Education," Soc. Sci., vol. 12, no. 6, pp. 1106-1111, 2017.

[9] D. Izfanna and N. A. Hisyam, "A comprehensive approach in developing akhlaq: A case study on the implementation of character education at Pondok Pesantren Darunnajah,” Multicult. Educ. Technol. J., vol. 6, no. 2, pp. 77-86, 2012.

[10] K. B. Noaparast, "Al-Attas revisited on the Islamic understanding of education," J. Shia Islam. Stud., vol. 5, no. 2, pp. 149-172, 2012.

[11] M. R. M. Nor and M. Malim, “Revisiting Islamic education: the case of Indonesia,” J. Multicult. Educ., 2014.

[12] N. R. N. Yaacob, "An Islamic perspective on the role of education in responding to social issues among students in Malaysia," US-China Educ. Rev., vol. 3, no. 6, pp. 2161-6248, 2013.

[13] D. F. Johnson-Mardones, "Understanding Curriculum as Phenomenon, Field, and Design: A Multidimensional conceptualizationi," Int. Dialogues Educ.

[14] S. R. MZ, "The Education Curriculum System of Boarding School," Tawazun J. Pendidik. Islam, vol. 9, no. 1, pp. 111-126, 2018.

[15] Z. Sherman, The curiosity of school: Education and the dark side of enlightenment. Penguin Canada, 2012.

[16] W. Warju, S. Ariyanto, and L. Muzaki, "Developing Integrated Curriculum with Environmental Education at Vocational High School," in International Conference on Indonesian Technical Vocational Education and Association (APTEKINDO 2018), 2018.

[17] R. Raharjo, "Pengembangan \& Inovasi Kurikulum,” Yogyak. Baituna Publ., 2012.

[18] I. Machali, "Kebijakan perubahan kurikulum 2013 dalam menyongsong Indonesia emas tahun 2045,” J. Pendidik. Islam, vol. 3, no. 1, pp. 71-94, 2014.

[19] N. Ahid, “Konsep dan Teori Kurikulum dalam Dunia Pendidikan,” Islam. J. Studi Keislam., vol. 1, no. 1, pp. $12-29,2006$.

[20] K. E. Bohlin, D. Farmer, and K. Ryan, Building Character in Schools Resource Guide. The Jossey-Bass Education Series. ERIC, 2001.

[21] M. Alzola, "Character and environment: The status of virtues in organizations," J. Bus. Ethics, vol. 78, no. 3, pp. 343-357, 2008.

[22] J. M. Doris, Lack of character: Personality and moral behavior. Cambridge University Press, 2002.

[23] O. J. Flanagan and O. J. Flanagan, Varieties of moral personality: Ethics and psychological realism. Harvard University Press, 2009.

[24] C. Peterson and M. E. Seligman, Character strengths and virtues: A handbook and classification, vol. 1. Oxford University Press, 2004.

[25] J. Radden and J. Z. Sadler, "Character virtues in psychiatric practice," Harv. Rev. Psychiatry, vol. 16, no. 6, pp. 373-380, 2008.

[26] A. Azra, Paradigma baru pendidikan nasional: Rekonstruksi dan demokratisasi. Penerbit Buku Kompas, 2002.

[27] U. Fajarini, "Peranan kearifan lokal dalam pendidikan karakter," SOSIO-Didakt. Soc. Sci. Educ. J., vol. 1, no. 2, pp. 123-130, 2014.

[28] S. Judiani, "Implementasi pendidikan karakter di sekolah dasar melalui penguatan pelaksanaan kurikulum," J. Pendidik. Dan Kebud., vol. 16, no. 9, pp. 280-289, 2010.

[29] A. Sudrajat, "Mengapa Pendidikan Karakter?,” J. Pendidik. Karakter., vol. 1, no. 1, 2011.

[30] M. A. Rosa, "Prinsip dasar dan ragam penafsiran kontekstual dalam kajian teks Al-Qur'an dan Hadis Nabi Saw," Holist. Al-Hadis, vol. 1, no. 2, pp. 171-224, 2015.

[31] A. Qodir, "Ethos Of Education And Welfare Of Muslim Migrants Case Study in Migrant Settlement of Pangkoh, Pulang Pisau Regency, Central Kalimantan Province.," J. Educ. Health Community Psychol., vol. 1, no. 2, 2012.

[32] M. Tajuddin, “Kontroversi Kemaksuman Rasul Ulu Al-‘Azmi Dalam Al-Qur'an (Studi Komparatif Tafsir AlThabarsi Dan Al-Qurthubi)."

[33] M. Iqbal, “Metode Penafsiran al-Qur'an M. Quraish Shihab,” Tsaqafah, vol. 6, no. 2, pp. 248-270, 2010.

[34] A. I. al-Zajjāj, Ma ānī al-Qur'ān wa-i 'rābuhu. 'Abd al-Jalīl Shalabī (ed.), 1988.

[35] C. S. V. Turner, “Guests in someone else's house: Students of color,” Rev. High. Educ., vol. 17, no. 4, pp. 355-370, 1994

[36] A. Mujahidin, "Analisis Simbolik Penggunaaaan Ayat-ayat Al-Quran Sebagai Jimat Dalam Kehidupapan Masyarakat Ponorogo,” KALAM, vol. 10, no. 1, pp. 43-64, 2016.

[37] M. Syahnan, "I 'jâz Al-Qur'ân in the Views of Al-ZamakhsyÂ̂rî and Sayyid Quthb,” Ulumuna, vol. 15, no. 2, pp. 249-264, 2011.

[38] A. M. Marâghî and A. Musthafa, “Tafsîr al-Marâghî, Juz I,” Beirut Dâr Al-Fikr Tt, 1946.

[39] Zulheldi, Metode Tafsir Tarbawi: Referensi Penelitian Tafsir Pendidikan. Rajawali Press, 2019. 